\title{
Substrate colonization and relative abundance of immature forms of black flies (Diptera: Simuliidae) in river Mada, Nasarawa State Nigeria
}

\author{
Ndubisi Raphael Uzoigwe ${ }^{1}$, Chukwuemaka Ikechukwu Njoku ${ }^{1}$, \\ Gideon Aduk Amuga $^{2 \star}$, Jael Asabe Yohanna ${ }^{3}$ \\ ${ }^{1}$ Epidemiology and Control Division, Onchocerciasis Research Department, Nigerian Institute for Trypanosomiasis Research (NITR), \\ Vom, Nigeria \\ ${ }^{2}$ Department of Biological Sciences, Nasarawa State University, Keffi, Nigeria; *Corresponding Author: kamuga2@yahoo.com \\ ${ }^{3}$ Department of Zoology, University of Jos, Jos, Nigeria
}

Received 15 June 2013; revised 20 July 2013; accepted 4 August 2013

Copyright (C) 2013 Ndubisi Raphael Uzoigwe et al. This is an open access article distributed under the Creative Commons Attribution License, which permits unrestricted use, distribution, and reproduction in any medium, provided the original work is properly cited.

\begin{abstract}
Black flies, vectors of Onchocerca volvulus, are known to colonize fast flowing sections of rivers. A study on aspects of ecology of immature forms of black flies was conducted at River Mada. Larvae and Pupae of the Genus: Simulium were prospected on natural substrates found at various water currents along the course of the river over a 12-month period. Larvae of six species and pupae of three species were identified colonizing different substrates in the river. A total of 443 larvae and 142 pupae were collected, and the peak month of collection was April. 405 (91.4\%) larvae were identified as $S$. damnosum sl while 38 (8.6\%) comprised S. adersi, S. hargreavesi, S. cervicornotum, S. bovis and S. vorax. 110 (77.5\%) of the pupae collected were $S$. damnosum sl while $32(22.5 \%)$ were $S$. adersi, and S. hargreavesi. The larvae unlike pupae appeared to be non discriminatory in substrate colonization and current preference. Paucity of the population of immature forms is observed and attributed primarily to scarcity of suitable substrates and other factors also discussed herein.
\end{abstract}

Keywords: Black Flies; Colonization; Immature Forms; Mada River; Relative Abundance;

Substrates

\section{INTRODUCTION}

Black flies (Simulium damnosum sl) are the principal vectors of Onchocerca volvulus, the causative agent of river-blindness disease (onchocerciasis) in Nigeria and other West African countries [1-3]. The flies breed in fast flowing well oxygenated rivers and streams which are numerous in Nigeria [2]. Besides acting as vectors of human onchocerciasis, black flies are important pests of livestock responsible for much economic losses in animal production through their bites and disease transmission $[4,5]$.

Two forms of river-blindness disease are known to occur in Nigeria. These are the savanna and forest types of the disease. The difference between the two types is the dominant specie of the vector and the strain of the parasite that is transmitted in each ecological zone [6]. Epidemiological studies have shown that the savanna form is characterized by blinding disease, while the forest type is less blinding but presents with onchocercal skin disease. In view of this, and the fact that communities close to rivers and streams that support the breeding of black flies are usually more affected by the biting nuisance and infection $[7,8]$, it becomes requisite to have a good knowledge of the distribution of the vectors for better understanding of the epidemiology of onchocerciasis in different endemic areas of the country.

Since the early reports on the distribution of breeding sites of black flies in Nigeria [2] several other reports have emerged from different ecological zones [9-11]. The river systems and large streams descending the Jos plateau are known to support different species of black flies $[9,10,12]$. This is resulting from suitable micro-environments enhanced by the fast flow and turbulence created as the water flows down the rocky embankment down to the lowland plateau. It is also due to abundant suitable natural substrates which the immature forms of the vector colonize $[13,14]$. The ecological distribution of breeding 
sites of black flies is determined by the availability of fast flowing water body, presence of suitable substrates and levels of pollution in the ambient environment. Several factors which affect the population of immature forms of the vectors, and the physico-chemical properties of their aquatic habitats are well reviewed $[9,15]$. Those that have greater influence include substrate availability, water velocity and $\mathrm{pH}$ of the water among many others.

As a step towards the determination of the risk status of communities and settlements along Mada River, the population dynamics and relative abundance of immature forms of black flies colonizing natural substrates in the river was investigated prior to a full entomological study of the activity of $S$. damnosum sl in the area.

\section{MATERIALS AND METHODS}

The study was conducted in a segment of Mada River at kilometer 12 along Akwanga-Keffi-Abuja road. The Mada River is perennial with its head waters coming from the edges of the Jos plateau. The river flows down the embankment of the high plateau to the lowland plain in Nasarawa state, before it discharges into River Benue. Like most rivers in the lowland areas of the plateau, the river floor is characterized by few obstructing rocks and long stretches of alluvial deposits. This brings about few rapids and less turbulent water flow. The fringing vegetation along the banks of the river provides intermittent shades and consists of the savanna-forest mosaic type.

Search for breeding sites and immature forms of black flies were conducted upstream from the bridge at kilometer 12 along Akwanga-Keffi-Abuja road. The downstream part of the river was prone to pollution due to human activities. Immature aquatic larvae and pupae of black flies were prospected for on natural substrates along the river. The exercise was conducted monthly for twelve months. Larvae and pupae were picked out from substrates with fine forceps and placed into glass tubes containing $80 \%$ alcohol solution. Materials collected from different substrates were so differently preserved before transportation to the laboratory for microscopic examination and identification. Only the matured larvae (showing dark gill spots) and pupae (with defining plastron gills) were identified. The keys of $[16,17]$ were used for identification of the larvae and pupae respectively. The river flow rate was estimated in the absence of a Pitot tube by the "float" method. The time taken for a cork float to cover a distance of two meters (one meter before and after an identified substrate) was determined using a stop watch. This was repeated three times, and the average distance in meter per second was determined.

\section{RESULTS}

Figure 1 shows the monthly abundance of larval populations of black flies in Mada River. A total of 443 mature larvae were collected and identified. S. damnosum sl constituted $90.3 \%$ of the population in river Mada. The other species include S. adersi (5.9\%), S. hargreavesi (2.5\%), S. bovis $(0.7 \%)$, S. vorax $(0.5 \%)$ and S. cervicornotum $(0.2 \%)$. Peak periods of larval abundance for the dominant specie ( $S$. damnosum sl) were recorded in the months of April (38.1\%), December (17.6\%) and January (15.6\%). No larvae were picked in the months of July and August.

Table 1 shows the natural substrates available and

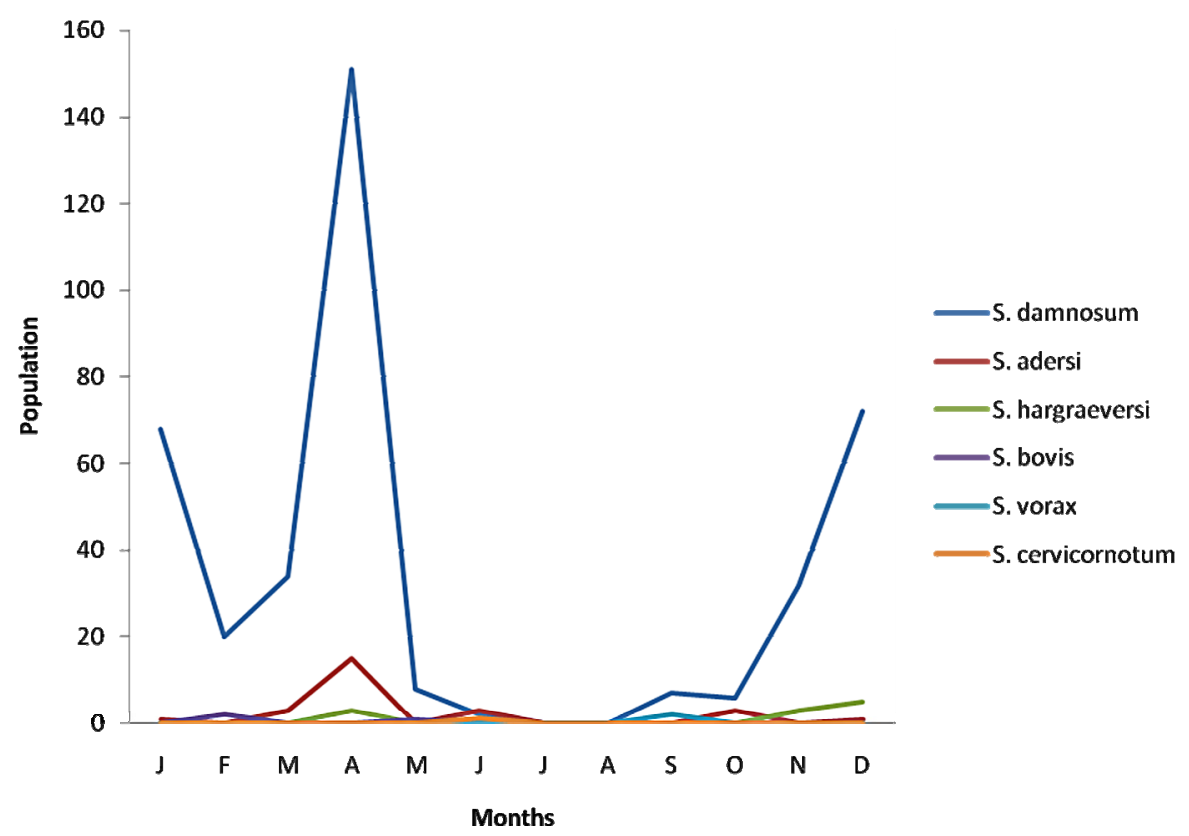

Figure 1. Monthly abundance of black fly larvae in Mada River, North Central Nigeria. 
Table 1. Substrate colonization of black fly larvae in Mada River.

\begin{tabular}{|c|c|c|c|c|}
\hline \multirow{2}{*}{ Black fly species } & \multicolumn{4}{|c|}{ Type of substrate (\% colonization) } \\
\hline & T/leaves & S/leaves & $\mathrm{S} / \mathrm{dw} / \mathrm{B}$ & Total \\
\hline \multirow{2}{*}{ S. damnosum sl } & 185 & 123 & 92 & 400 \\
\hline & $(46.3)$ & (39.8) & $(23.0)$ & $(100)$ \\
\hline \multirow{2}{*}{ S. adersi } & 9 & 9 & 8 & 26 \\
\hline & (34.6) & (34.6) & (30.8) & $(100)$ \\
\hline \multirow{2}{*}{ S. hargraeversi } & 6 & 0 & 5 & 11 \\
\hline & $(54.5)$ & $(0.0)$ & $(45.5)$ & $(100)$ \\
\hline \multirow{2}{*}{ S. bovis } & 1 & 2 & 0 & 3 \\
\hline & (33.3) & $(66.7)$ & $(0.0)$ & $(100)$ \\
\hline \multirow{2}{*}{ S. vorax } & 2 & 0 & 0 & 2 \\
\hline & $(100)$ & $(0.0)$ & $(0.0)$ & $(100)$ \\
\hline \multirow{2}{*}{ S. cervicornotum } & 1 & 0 & 0 & 1 \\
\hline & $(100)$ & $(0.0)$ & $(0.0)$ & $(100)$ \\
\hline \multirow{2}{*}{ Total } & 204 & 134 & 105 & 443 \\
\hline & (46.1) & $(30.2)$ & (23.7) & (100) \\
\hline
\end{tabular}

Key: T/leaves $=$ Trailing leaves; S/leaves $=$ Submerged dead leaves; $\mathrm{S} / \mathrm{dw} / \mathrm{B}=$ Submerged dead wood/Branch.

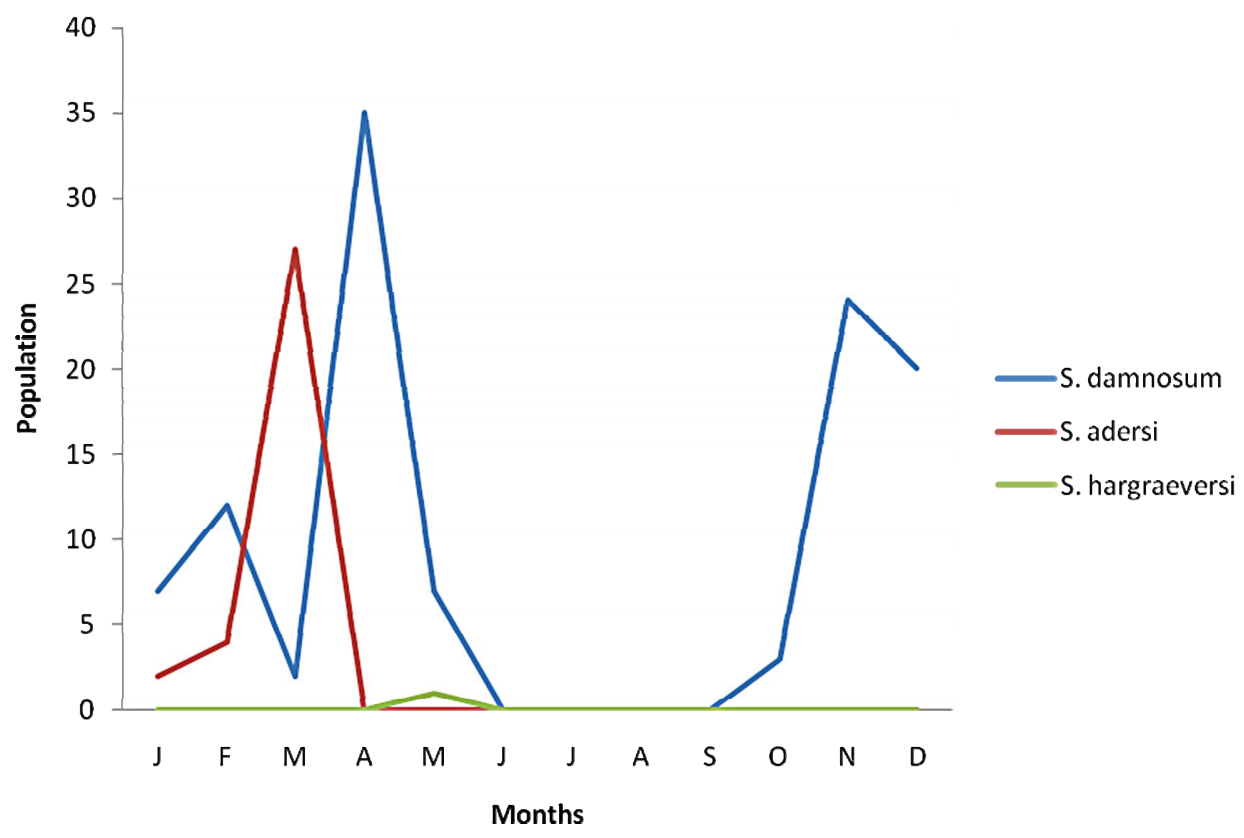

Figure 2. Monthly abundance of black fly pupae in Mada River, North Central Nigeria.

Table 2. Substrate colonization of black fly pupae in Mada River.

\begin{tabular}{ccccc}
\hline \multirow{2}{*}{ Black fly species } & \multicolumn{3}{c}{ Type of substrate (\% colonization) } \\
\cline { 2 - 5 } & T/leaves & S/leaves & S/dw/B & Total \\
\hline S. damnosum sl & 44 & 44 & 22 & 110 \\
S. adersi & $(40.0)$ & $(40.0)$ & $(20.0)$ & 33 \\
& 0 & 0 & 33 & $(100)$ \\
S. hargraeversi & $(0.0)$ & $(0.0)$ & $(100)$ & 1 \\
& 1 & 0 & 0 & $(100)$ \\
Total & $(100)$ & $(0.0)$ & $(0.0)$ & 144 \\
& 45 & 44 & 55 & $(100)$ \\
\hline
\end{tabular}

Key: T/leaves $=$ Trailing leaves; S/leaves $=$ Submerged dead leaves; S/dw/B = Submerged dead wood/Branch. 
colonized by black fly larvae in river Mada. Trailing leaves $(46.1 \%)$ were the most colonized substrates, followed by submerged dead leaves (30.2\%) and submerged dead wood and branches (23.7\%). Grass and shrub roots exposed in water as well as rocks partially covered by flowing river were not colonized by black fly species. $S$. damnosum, S. adersi, S. hargreaversi, S. vorax and S. cervicornotum showed more preference for trailing leaves while submerged dead leaves were more preferred by $S$. bovis.

Figure 2 shows monthly abundance of pupae in the study area. A total of 144 pupaes were collected consisting of S. damnosum s l (76.4\%), S. adersi (22.9\%) and S. hargrevesi $(0.7 \%)$. More pupaes were collected in the month of April (25.0\%) and less in October (0.2\%) No pupae species were found in the months of June to September.

Table 2 shows the pattern of substrate colonization by pupae in river Mada. More pupaes colonized submerged dead wood and branches (38.2\%) and trailing leaves (31.3\%). The pupae of S. damnosum and S. hargreaversi showed preference for trailing leaves while those of $S$. adersi preferred submerged dead wood and branches. The pupaes that were present did not attach on either roots or rock surface. No immature stages were collected in June and July due to inaccessibility of the river bank in those months. The river flow rate in the months collections was made ranged between $0.7 \mathrm{~m} / \mathrm{s}$ and $1.6 \mathrm{~m} / \mathrm{s}$.

\section{DISCUSSION}

The presence of larvae and pupae on substrates in Mada River is an indication that the river supports breeding of black flies include the medically important $S$. damnosum sl. Our observation corroborates earlier observation [2,11]. Immature forms (larvae and pupae) were present in all the months prospection was made. Excessive over flooding and fast flow of the river made it very unsafe for prospecting in the months of July and August. However, the absence of record of larvae and pupae in both months does not translate to inactivity of the vector in the river because adult fly activity has been reported elsewhere in the same months $[18,19]$.

Altogether, immature forms of six species were found in the river colonizing some of the available substrates. $S$. damnosum sl, the known vector of onchocerciasis was the most dominant specie in each month. The adults of this specie were similarly found to be dominant at Ogun River but with low vectoral capacity [20]. Larvae and pupae belonging to this specie colonized three of the natural substrates viz, trailing leaves, submerged dead leaves and wood. Roots and rock surfaces were not colonized by the specie. The non-colonization of both substrates could be attributed to the perennial nature of the river which consistently covers other substrates in the river all year round. Unlike annual river systems where the water level gets very low and almost dries out at the peak of dry season and immature forms are seen overcrowding any covered substrates in the water such as roots (personal observations).

$S$. adersi was the next common specie in the river. This specie and the others ( $S$. hargrevesi, S. cervicornotum, S. bovis and S. vorax) are however not of any human medical importance. More pupaes were found after the months of rain. This could be due to mild water currents that ensured. This period marks the beginning of hot weather which affects water temperature and enhance development of immature stages [21]. Only three pupae species of the six larvae species were seen. These were $S$. damnosum sl, which colonized all the three substrates, $S$. hargreavesi found only on trailing leaves and $S$. adersi which colonized both submerged dead leaves and wood.

The notable paucity of immature black flies in the river stems from flooding and overflowing of the river in the months of rains which results in covering most of the natural substrates [19,22]. Ovipositing becomes affected due to the limited substrates that are still available for the deposition of eggs, attachment of hatching out larvae and developed pupae. In a different study carried out in the same river [9], a total of eleven species of immature forms were found. The species were however collected from both natural and artificial substrates. Hence paucity of substrates in River Mada is also contributory to the fewness and clustering of different species and different aquatic life stages of the vector on the limited substrates available.

By River Assop on the high plateau in central Nigeria, pupae of black flies show preference to round smooth substrates in the form of strips and strings [23]. Also a study on natural substrate colonization [13] revealed that pupae have high affinity to grass substrates. Very few grasses are available in the river for possible colonization. Another possible cause for the observed low population of aquatic forms is parasitism which has been reported in the river [18]. It was observed that immature forms especially larvae were highly parasitized by Microsporidia species and Mermithids.

Considering the low population of immature S. damnosum sl observed in this study, it is important to know whether this translates to lower onchocerciasis risk in the communities along the river. The confirmation will therefore be through further study of transmission and epidemiology within the communities.

\section{ACKNOWLEDGEMENTS}

The authors acknowledge the logistic support from NITR, Vom and are grateful to the technical staff in the Epidemiology and Control Division of Onchocerciasis Department NITR, Vom for assistance in the field. We also thank the Drivers in the maintenance Unit. 


\section{REFERENCES}

[1] Vagime, C.G. and Quillevere, D. (1978) The distribution of the Simulium (Edwardsellum) damnosum complex in West Africa with particular reference to the Onchocerciasis control programme area. Tropical Medical Parasitology, 29, 473- 482.

[2] Crosskey. R.W. (1981) A review of Simulium damunosum (s l) and human Onchocerciasis in Nigeria, with specialto geographical distribution and development of national control campaign. Tropical Medical Parasitology, 32, 2-16.

[3] Mafuyai, H.B., Post, R. J., Vajime, C.G. and Molyneux, D.H. (1996) Cytotaxonomic identification of the Simulium damnosum complex (Diptera: Simuliidea) from Nigeria. Tropical Medicine \& International Health, 6, 779785.

[4] Crosskey, R.W. (1973) Simuliidae as disease vectors. In: Smith, K. G. V., et al., Ed., Insects and Other Arthropods of Medical Importance, British Museum of Natural History, London, 109-153.

[5] Adeleke, M.A., Mafiana, C.F., Sam-Wobo, S.O., Olatunde, G.O., Ekpo, U.F. and Akinwale, O.P. (2010) Biting behavior of Simulium damnosum complex and onchocerca volvulus infection along Osun River, Southwest Nigeria. Parasite and Vector, 3, 1-5.

[6] WHO (1995) Oncchocerciasis and its control. Report of a WHO Expert Committee on Onchocerciasis control. World Health Organization Technical Report Series No. 852, World Health Organization, Geneva.

[7] Akogun, O.B. and Onwuliri, C.O.E. (1991) Hyperendemic onchocerciasis in the Taraba River valley of gongola State (old Adamawa provience) Nigeria. Annales De Parasitologie Humaine et Comparée, 66, 22-26.

[8] Uzoigwe, N.R., Dede, P.M., Ufomadu, G.O. and Onyeka, J.O.A. (2006) Activity of Simulium damnosum (dipteral; Simuliidae) complex in Dadin-Kowa hydroelectric Dam site in Yalmatu/ Deba LGA, Gombe State Nigeria. Nigerian Journal of Entomology, 23, 26-29.

[9] Egwuma, P.O. (1989) A study of the morphology and cytotaxonomy of larvae of Simulium species in some river systems of Plateau State-Nigeria. M.Sc. Thesis, University of Jos, Jos, 102p.

[10] Mafuyai, H.B. (1992) Studies on the taxonomy and distribution of the Simulium Damnosum complex in Nigeria in relation to human onchocerciasis. Ph.D. Thesis, University of Salford, Salford, 240p.

[11] Atting, I.A., Ejezie, G.C., Braide, E.I., Opara, K.N. and Ekwe, A. (2005) Seasonal variations in human onchocerciasis transmission by black flies (Simulium damnosum sl) in a forest area of Cross River State. Nigeria. African Journal of Applied Zoology and Environment, 4, 16-19.

[12] Roberts, D.M. and Okafor, B.C. (1987) Microdistribution of immature African Black flies resulting from water velocity and turbulence preference. Medical and Veterinary Entomology, 1, 169-175. http://dx.doi.org/10.1111/j.1365-2915.1987.tb00339.x

[13] Maduabum, M.A. (1982) Effects of substrates on the relative abundance of black flies (Simuliidae) pupae population in the River Assop Plateau State, Nigeria. Proceeding of 1st National Conference on Onchocerciasis, Kaduna, 1-4 September 1982, 10-11.

[14] Roberts, D.M. (1983) The relative abundance of pupae of three black flies species (Simulium spp) on different diameters of strings. Entomologie experiment et Applicata, 33, 125-128.

[15] Carlsson, G. (1967) Environmental factors influencing black fly population. Bulletin of World Health Organization, 37, 139-150.

[16] Crosskey, R.W. (1969) A reclassification of the Simuliidae (Diptera) of Africa and its islands. Bulletin of British Museum of Natural History on Entomology, Supplement 14, United States Department of Agriculture, London.

[17] Freeman, P. and De-Mellon, B. (1953) Simuliidae of Ethopian Region. London, British Museum of Natural History. Pp 178-203.

[18] Uzoigwe, N.R. and Onwuliri, C.O.E. (2000) Microsporidia and Mermithid parasitism of Simulium damnosum (sl) larvae in River Mada on the lowland area of the Jos Plateau. Journal of Pest, Disease and Vector Management, 2, 146-150.

[19] Adeleke, M.A., Sam-Wobo, S.O., Olatunde, G.O., Akinwale, O.P., Ekpo, U.F. and Mafiana, C.F. (2011) Bioecology of Simulium damnosum (theobald complex) along Osun River, Southwest Nigeia. Journal of Tropical Public health, 10, 39-43.

[20] Sam-Wobo, S.O., Adeleke, M.A., Jayeola, O.A., Adeyi, A.O., Oluwole, A.S., Adewale, B., Mafiana, C.F., Bissan, Y., Toe, L., Yameogo, L., Mutabaruka, E. and Amazigo, U.V. (2013) Seasonal fluctuation of Simulium damnosum complex in river systems, south-west Nigeria. International Journal of Tropical Insect Science, 33, 2-7. http://dx.doi.org/10.1017/S1742758412000434

[21] Cheke, R.A. (2011) The Thermal constant of Onchocerciasis vector, Simulium damnosum sl in West Africa. Medical and Veterinary Entomology, 26, 236-238. http://dx.doi.org/10.1111/j.1365-2915.2011.00980.x

[22] Ibe, O.O., Nwoke, B.E.B. and Adegoke, J.A. (2007) Distribution and ecology of breeding sites of Simulium damnosum s.l in south-eastern primary health zone of Nigeria. Nigerian Journal of Parasitology, 28, 32-38.

[23] Roberts, D.M. (1986) Some factors affecting substrate preferences by black fly Pupae (Diptera: Simuliidae). International Journal of Tropical Insect Science, 7, 107109. 